\title{
Trichoderma viride cellulase induces resistance to the antibiotic pore-forming peptide alamethicin associated with changes in the plasma membrane lipid composition of tobacco BY-2 cells
}

Mari Aidemark', Henrik Tjellström²,3, Anna Stina Sandelius ${ }^{3}$, Henrik Stålbrand $^{4}$, Erik Andreasson ${ }^{5}$, Allan G Rasmusson', Susanne Widell ${ }^{1 *}$

\begin{abstract}
Background: Alamethicin is a membrane-active peptide isolated from the beneficial root-colonising fungus Trichoderma viride. This peptide can insert into membranes to form voltage-dependent pores. We have previously shown that alamethicin efficiently permeabilises the plasma membrane, mitochondria and plastids of cultured plant cells. In the present investigation, tobacco cells (Nicotiana tabacum L. cv Bright Yellow-2) were pre-treated with elicitors of defence responses to study whether this would affect permeabilisation.

Results: Oxygen consumption experiments showed that added cellulase, already upon a limited cell wall digestion, induced a cellular resistance to alamethicin permeabilisation. This effect could not be elicited by xylanase or bacterial elicitors such as flg22 or elf18. The induction of alamethicin resistance was independent of novel protein synthesis. Also, the permeabilisation was unaffected by the membrane-depolarising agent FCCP. As judged by lipid analyses, isolated plasma membranes from cellulase-pretreated tobacco cells contained less negatively charged phospholipids (PS and PI), yet higher ratios of membrane lipid fatty acid to sterol and to protein, as compared to control membranes.

Conclusion: We suggest that altered membrane lipid composition as induced by cellulase activity may render the cells resistant to alamethicin. This induced resistance could reflect a natural process where the plant cells alter their sensitivity to membrane pore-forming agents secreted by Trichoderma spp. to attack other microorganisms, and thus adding to the beneficial effect that Trichoderma has for plant root growth. Furthermore, our data extends previous reports on artificial membranes on the importance of lipid packing and charge for alamethicin permeabilisation to in vivo conditions.
\end{abstract}

\section{Background}

Plants possess defence systems against microorganisms that are evolutionary conserved, as well as more specialised systems that are only found in certain taxa. The conserved defence system is often referred to as the innate immunity system and this has been overcome by

\footnotetext{
* Correspondence: Susanne.Widell@cob.lu.se

'Department of Biology, Lund University, Sölvegatan 35, SE-223 62 LUND, Sweden

Full list of author information is available at the end of the article
}

many successful pathogens [1] via production of poreforming toxins or injection of pathogen effectors through pores in the plant plasma membrane [2]. Many pathogenic actions can be counteracted by recognition events via receptors coded by resistance genes [3]. The triggered defence responses are elicited by signals, either derived from the invading organism (pathogen-associated or microbe-associated molecular patterns; PAMP and MAMP, respectively) or from the plant (host-associated molecular patterns). One response is to induce 
programmed cell death at the attacked site, elicited by hrp gene products such as the pore-forming peptide harpin [4] or by products of $a v r$ genes like AvrD [5]. Depending on the type of threat, the final outcome can also be production of antimicrobial agents, strengthening of physical barriers such as the cell wall or detoxification of pathogen toxin [6].

Some non-pathogenic organisms e.g., the fungi Trichoderma spp. that live in the rhizosphere are antagonistic to plant pathogens, yet induce defence responses in the plants [7-10]. Several elicitors for plant defence have been identified in Trichoderma species and strains e.g., xylanase [11], hydrophobin-like proteins [12], secondary metabolites [10,13] and peptaibols [14]. The peptaibol alamethicin elicits emission of volatiles [15], induces long distance signalling [16] and also apoptosis-like death of plant cells [17]. Besides being elicitors to defence responses, the channel-forming peptaibols secreted by Trichoderma also kill pathogenic fungi and bacteria around the root $[18,19]$. Therefore, a diverse array of antimicrobial peptides isolated from Trichoderma and other organisms have been explored for use in plant disease control [20]. The properties of alamethicin from $T$. viride have been most intensely investigated $[21,22]$. This peptide is hydrophobic, 20 residues long and rich in $\alpha$-amino isobutyric acid [23]. Its hydrophobic nature allows it to be inserted into biological membranes and form unspecific ion channels (pores) traversing the membranes. After insertion, the cells leak and eventually become lysed [24]. In artificial systems, pores will only form through membranes that have a transmembrane potential, and only when the alamethicin is applied from the net positive compartment $[21,25]$. Such a polarity of permeabilisation has been shown also in vivo in tobacco cells, where the plasma membrane (negative transmembrane potential) but not the tonoplast (positive transmembrane potential) was permeabilised by alamethicin added to cells [26]. With artificial membranes, several peptide molecules may oligomerise in membrane to form a barrel-stave complex with up to approximately $10 \AA$ pore size, if a sufficient concentration of alamethicin is present [27]. Besides a negative transmembrane potential, pore formation also depends on peptide concentration, lipid/peptide ratio, lipid species, $\mathrm{pH}$ and ionic concentration [25,28-30]. For example, varying the size of the headgroups in artificial phospholipid bilayers affected the concentration of alamethicin needed for permeabilisation [31].

Recently, we have shown that alamethicin forms pores in plant plasma membranes, the inner mitochondrial membrane and the plastid inner envelope $[26,28,32]$. In short-term experiments (10 min exposure to alamethicin) with tobacco BY-2 and Arabidopsis col-0 cell cultures, metabolic processes could be investigated in situ, i.e., when the crowdedness of the cytosol/organelle was left intact. The permeabilisation of isolated mitochondria was nearly instantaneous [28] whereas it took several min for the plasma membrane to be completely permeabilised [26,32] suggesting that either the cell wall constituted a barrier for diffusion for alamethicin, or membrane composition affected the rate of permeabilisation.

The fact that alamethicin permeabilises plant membranes might appear incomprehensible with a beneficial role of $T$. viride. However, our experiments were done with sterile cells that had not been exposed to T. viride, and the situation is far from the soil situation where fungus and plant grow together and influence each other. The objective of the present investigation was to investigate if different treatments of plant cells known to induce defence responses, affect subsequent permeabilisation by alamethicin. Upon alamethicin permeabilisation the cells become depleted of respiratory metabolites. Effects of different agents on permeabilisation can therefore be monitored as differences in respiration rate decline upon alamethicin addition. Since alamethicin pore formation depends on several parameters (e.g., transmembrane potential and lipid composition), these properties were analysed using uncouplers and isolated plasma membranes, respectively. We here show that cellulase, unlike several other agents, made the cells resistant to subsequent alamethicin permeabilisation. Furthermore, plasma membranes isolated from cellulase-treated cells were altered in their lipid composition. We suggest that the cellulase activity induces a defence system in the plant cells and that this makes them resistant to alamethicin. These results thus provide a possible explanation for how Trichoderma ssp. can have beneficial effects without damaging the plants.

\section{Results}

Tobacco cells treated with cell wall degrading enzymes become resistant to alamethicin

Cultured tobacco cells respire with a relatively constant rate as long as they are intact, which can be monitored using an oxygen electrode (Figure 1). Upon alamethicin addition, the respiration rate declines over $10 \mathrm{~min}$, during which time the cells become depleted for substrates and coenzymes [26]. When the cells were pre-exposed to cell wall degrading enzymes (cellulase and macerozyme in $0.35 \mathrm{M}$ mannitol, $\mathrm{pH} 5.0$; CM) for $4 \mathrm{~h}$ they retained $60 \%$ of the respiration after alamethicin addition compared to approximately $20 \%$ for cells incubated in Control medium (0.35 M mannitol, pH 5.0). At this stage of limited wall degradation, cells still retained their shape, but cell separation had begun. No visual changes in intracellular morphology (e.g. vacuolisation) between these cells were observed (Additional file 1). The 

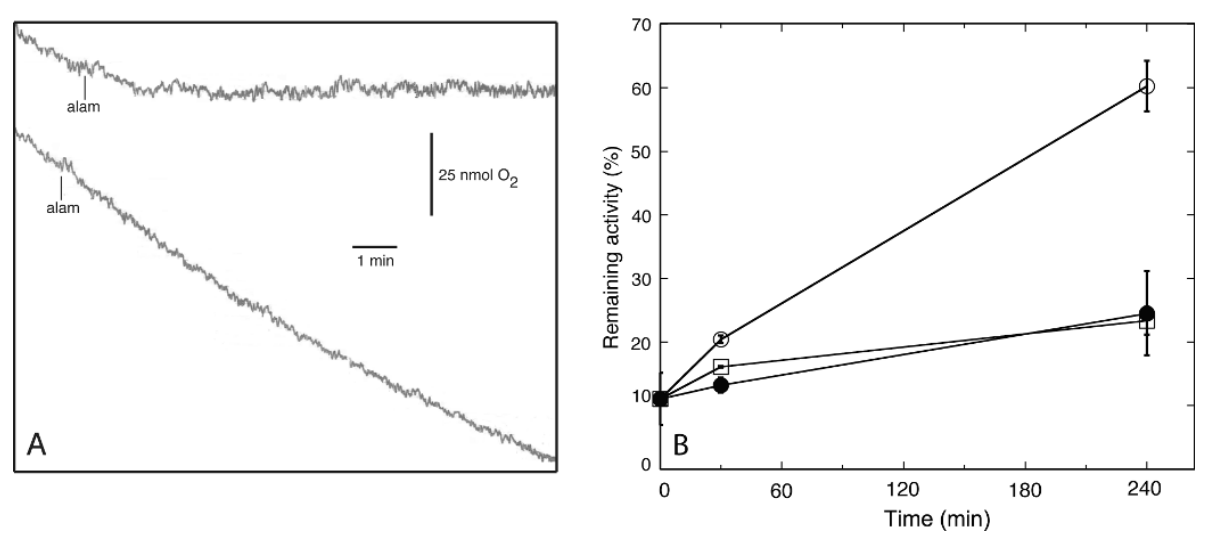

Figure 1 The effect of alamethicin on oxygen consumption of tobacco cells pretreated with cellulase and macerozyme (CM) (A) Respiration in Control cells (upper trace) and cells treated for $4 \mathrm{~h}$ with CM (lower trace). Alam, addition of alamethicin. (B) Alamethicin resistance after different incubation times in Control medium and CM, respectively. Resistance was measured as per cent of respiration rate remaining after 10 min incubation with $20 \mathrm{~g} \mathrm{ml}^{-1}$ alamethicin compared to the initial rate. Squares are control samples, open circles are CM-treated samples, and filled circles are samples treated with boiled CM. Values represent the mean of three biological replicates and the error bars denote SE.

concentrations of cellulase and macerozyme in the $\mathrm{CM}$ mixture ( $1 \%$ and $0.1 \%$, respectively) are the ones commonly used in the isolation of protoplasts, but higher temperatures than used here are needed for a removal of the cell wall to occur within $4 \mathrm{~h}$. After the same incubation at higher temperatures the resulting protoplasts, fully devoid of cell wall, were also found to be alamethicin-resistant (results not shown). However, since additional cellular changes are associated with protoplast formation, we did not further investigate protoplasts. Inactivating the enzymes by boiling before $\mathrm{CM}$ incubation prevented the elicitation of resistance (Figure 1), suggesting that the enzyme-induced activity on the cell wall was needed for the response. Also, lowering the incubation time in the $\mathrm{CM}$ medium to an initial $20 \mathrm{~min}$ followed by washing and incubation for $220 \mathrm{~min}$ with Control medium alone resulted in similar resistance compared to the full $4 \mathrm{~h}$ enzyme treatment (Table 1 ). The DNA stain propidium iodide cannot pass the plasma membrane of intact cells and can therefore be used as direct indicator of alamethicin permeabilisation [32]. Control cells showed strong fluorescence of the

$\begin{aligned} & \text { Table } 1 \text { Alamethicin resistance of tobacco cells treated } \\
& \text { with CM for different times before transfer to Control } \\
& \text { medium }\end{aligned}$
\begin{tabular}{lll} 
Incubation in CM- & Postincubation in Control \\
medium (min) & medium (min) & $\begin{array}{l}\text { Resistance } \\
(\%)\end{array}$ \\
\hline 240 & 0 & $71 \pm 1.4$ \\
20 & 220 & $84 \pm 5.6$ \\
0 & 240 & $25 \pm 3.0$ \\
\hline
\end{tabular}

Resistance was measured as per cent of respiration rate remaining after 10 min incubation with $20 \mu \mathrm{g} \mathrm{ml}^{-1}$ alamethicin compared to the initial rate. Average of two independent experiments are shown with error bars representing SD. nucleus after incubation with alamethicin and propidium iodide (Figure 2), while only a faint signal could be observed in cells treated for $20 \mathrm{~min}$ with $\mathrm{CM}$ medium, followed by $220 \mathrm{~min}$ with Control medium (Figure 2). No staining was observed in the absence of alamethicin in any cells.

In the above experiments, $20 \mu \mathrm{g} \mathrm{ml}^{-1}$ alamethicin was used to permeabilise the cells. We compared the concentration dependence of alamethicin permeabilisation between control cells and CM-treated cells, and significant differences were observed over an extended range (Figure 3). At $40 \mu \mathrm{g} \mathrm{ml}^{-1}$ alamethicin, also CM-treated cells became permeabilised, though not to the same extent as control cells (Figure 3). The concentration dependency showed a sigmoid pattern with both control and CM cells. Approximately three times the concentration of alamethicin was needed with CM-treated cells compared to control cells to yield a $50 \%$ permeabilisation, i.e., $30 \mu \mathrm{g} \mathrm{ml}^{-1}$ for CM cells compared to less than $10 \mu \mathrm{g} \mathrm{ml}^{-1}$ for control cells (Figure 3).

\section{Alamethicin resistance of tobacco cells is mainly due to the effect of cellulase}

In the initial experiments, cells were treated with a combination of cellulase and macerozyme in mannitol (CM). To determine whether both enzymes were needed for the elicitation of alamethicin resistance we also treated cells with each of the enzymes separately. It was found that cellulase was more important than macerozyme for the development of resistance, since cellulase alone induced almost the same level of resistance as the CM treatment did (Table 2). As little as $0.05 \%$ cellulase, one twentieth of the concentration normally used in a protoplast preparation mix, gave an increased resistance to 


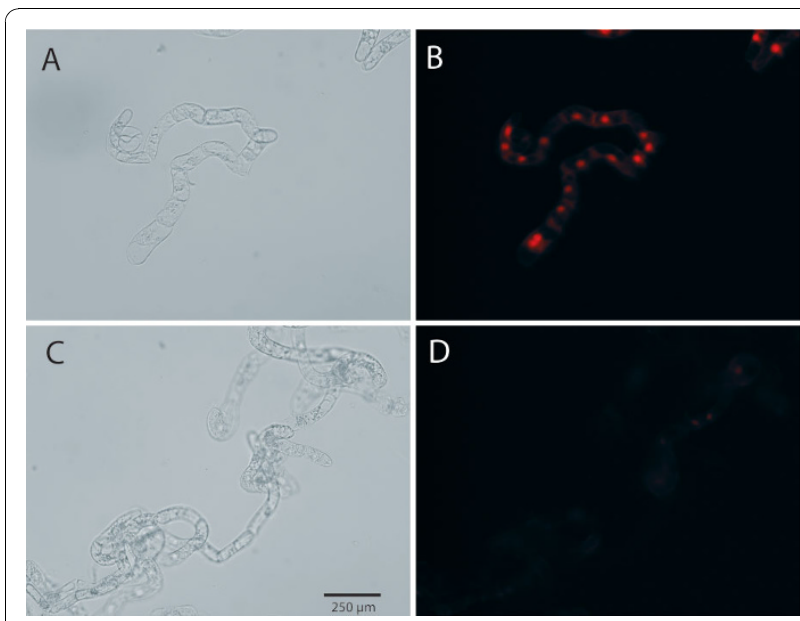

Figure 2 Propidium iodide staining of alamethicin-treated tobacco cells. Bright field (A) and (C) and fluorescent (B) and (D) images are shown for cells after incubation with $20 \mathrm{~g} \mathrm{~m}^{-1}$ alamethicin for $10 \mathrm{~min}$. Before addition of alamethicin, cells were pretreated with either Control medium for $4 \mathrm{~h}(\mathrm{~A}, \mathrm{~B})$ or $\mathrm{CM}$ medium for $20 \mathrm{~min}$ followed by $220 \mathrm{~min}$ with Control medium (C, D). The bar is valid for all images.

alamethicin relative to the control. With $0.1 \%$ macerozyme alone (the concentration normally used in a protoplastation mix) a limited resistance developed (Table 2).

Cellulase from $T$. viride contains a mixture of endoglucanases, exoglucanases and $\beta$-glucosidases [33]. Both the endo- and exoglucanases of the T. viride cellulase

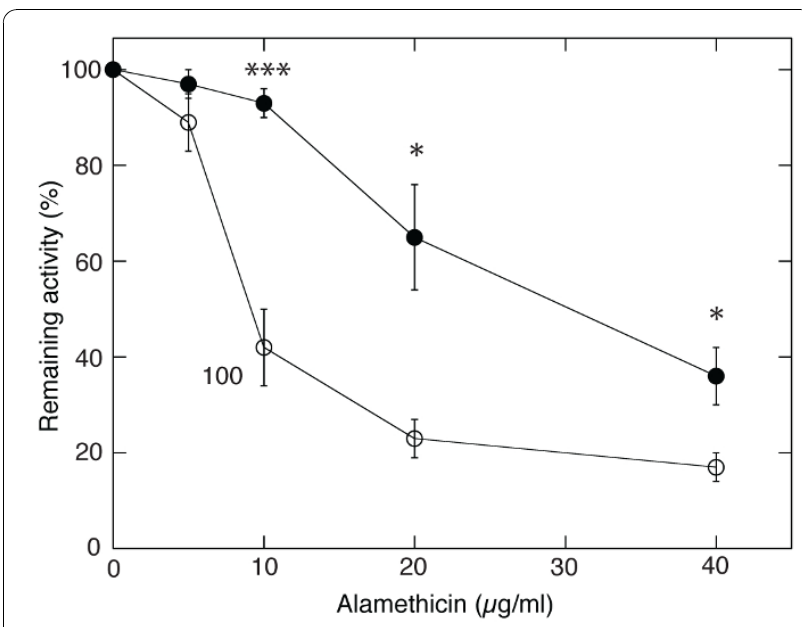

Figure 3 Remaining respiration in control and CM-treated tobacco cells after adding different concentrations of alamethicin. Open circles, control cells; filled circles CM-treated cells. Resistance was measured as per cent of respiration rate remaining after $10 \mathrm{~min}$ incubation with $20 \mathrm{\mu g} \mathrm{ml}^{-1}$ alamethicin compared to the initial rate. Each data point represents the mean of four biological replicates and the error bars represent SE. Significant differences (Student's t-test) between CM cells and control are denoted with ${ }^{*}$ for $p<0.05$ and ${ }^{* * *}$ for $p<0.001$.
Table 2 Alamethicin resistance of tobacco cells treated with different concentrations of cellulase and macerozyme

\begin{tabular}{lll}
\hline Cellulase (\%) & Macerozyme (\%) & Resistance (\%) \\
\hline 0 & 0 & $27.1 \pm 4.4$ \\
1 & 0.1 & $74.2 \pm 5.6$ \\
1 & 0 & $64.0 \pm 4.2$ \\
0.05 & 0 & $43.8 \pm 3.9$ \\
0 & 0.1 & $37.3 \pm 5.3$ \\
0 & 0.05 & $29.2 \pm 4.0$ \\
\hline
\end{tabular}

Resistance was measured as per cent of respiration rate remaining after 10 min incubation with $20 \mathrm{\mu g} \mathrm{ml}^{-1}$ alamethicin compared to the initial rate. Average of two independent experiments are shown with error bars representing SD.

are product-inhibited by cellobiose, while the $\beta$-glucosidase is product-inhibited by glucose [34,35]. Because of this, we tested to inhibit the induction of alamethicin resistance by adding glucose and cellobiose to the incubation mixture. The concentrations used were considerably higher than reported $K_{i}$ values for endo/exoglucanases and $\beta$-glucosidase, and thus significant inhibition of the enzymes can be assumed [34-37]. Addition of cellobiose alone lowered the alamethicin resistance induced by enzyme treatment of cells (Figure 4). This effect increased when $0.1 \mathrm{M}$ glucose was included with the cellobiose to inhibit $\beta$-glucosidase degradation of the cellobiose. Glucose by itself had no effect on the alamethicin resistance of CM treated samples (Figure 4). The observation that cellulase inhibition reduced the resistance to alamethicin shows that the cellulase activity is important for the elicitation of alamethicin resistance.

The cellulase preparations used are relatively crude and effects seen could potentially be batch-dependent. However, similar degrees of resistance could be induced using a second cellulase batch from the same supplier (Yakult Honsha) and one from Serva (Table 3). Both these cellulases are from $T$. viride. In contrast, no resistance could be induced by Celluclast, a cellulase mixture that is isolated from $T$. reese $i$ and used to degrade cellulose industrially (Table 3 ). After establishing that endoglucanases or exoglucanases in the cellulase mixture were the main source of the elicited alamethicin resistance we tested additional enzymes for elicitation potential. No resistance was obtained after incubating cells 4 $\mathrm{h}$ with $T$. reesei endoglucanase $\operatorname{TrCel} \mathrm{B}$ cor or $T$. reese $i$ endomannanase TrMan5A (Table 3).

\section{Several common plant elicitors did not induce alamethicin resistance}

To find out how general the alamethicin resistance response was, other elicitors of defence responses in plants were investigated. No resistance to alamethicin was induced by $4 \mathrm{~h}$ incubation with xylanase, elf18, 


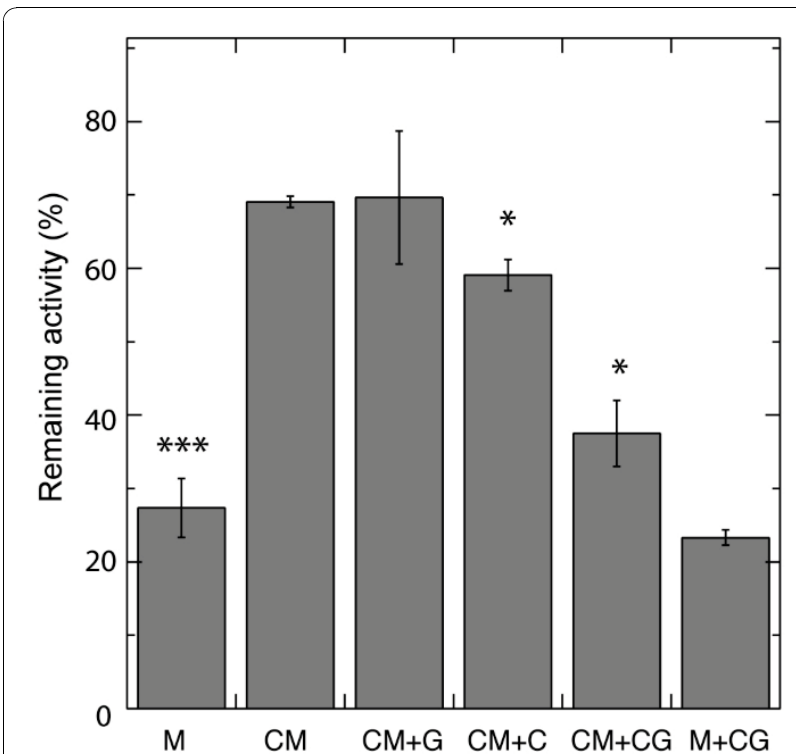

Figure 4 Effect of inhibition of cellulase activity on the induction of alamethicin resistance of tobacco cells. Resistance was measured as per cent of respiration rate remaining after $10 \mathrm{~min}$ incubation with $20 \mathrm{\mu g} \mathrm{ml}^{-1}$ alamethicin compared to the initial rate. Samples were pre-incubated with combinations of $1 \%$ cellulase, $0.1 \%$ macerozyme, $0.1 \mathrm{M}$ glucose, and $0.1 \mathrm{M}$ cellobiose in $0.35 \mathrm{M}$ mannitol for $20 \mathrm{~min}$ followed by $220 \mathrm{~min}$ with control medium only. Where glucose or cellobiose was included, the concentration of mannitol in the control medium was reduced to give a similar molarity. M, control cells, CM, CM-treated cells, G, glucose, C, cellobiose. Data shown are averages of two biological replicates and error bars represent SD. Student's t-test was performed relative to the CM sample with * denoting $p<0.05$ and ${ }^{* * *}$ denoting $p<$ 0.001

flg22 or chitosan (Figure 5). As positive controls for the treatments with xylanase, elf 18 and flg 22 treatments, MAP kinase activation was monitored after these treatments (results not shown). A low level of alamethicin resistance could be seen after treatment with $1 \mathrm{mM}$ $\mathrm{H}_{2} \mathrm{O}_{2}$ (Figure 5). However, adding catalase during $\mathrm{CM}$ treatment did not prevent the induction of alamethicin resistance (Additional file 2). None of the elicitors

Table 3 Alamethicin resistance of cells treated with different cell wall degrading enzymes or enzyme modules

\begin{tabular}{lll}
\hline Enzyme & Source species & Resistance (\%) \\
\hline Cellulase (Yakult) & T. viride & $76 \pm 12$ \\
Cellulase (Serva) & T. viride & $75 \pm 9$ \\
Celluclast & T. reesei & $18 \pm 5$ \\
TrCel7Bcor module & T. reesei & $22 \pm 3$ \\
TrMan5A module & T. reesei & $19 \pm 2$ \\
\hline
\end{tabular}

Resistance was measured as per cent of respiration rate remaining after 10 min incubation with $20 \mathrm{\mu g} \mathrm{ml}^{-1}$ alamethicin compared to the initial rate. Average of two independent experiments are shown with error bars representing $S D$.

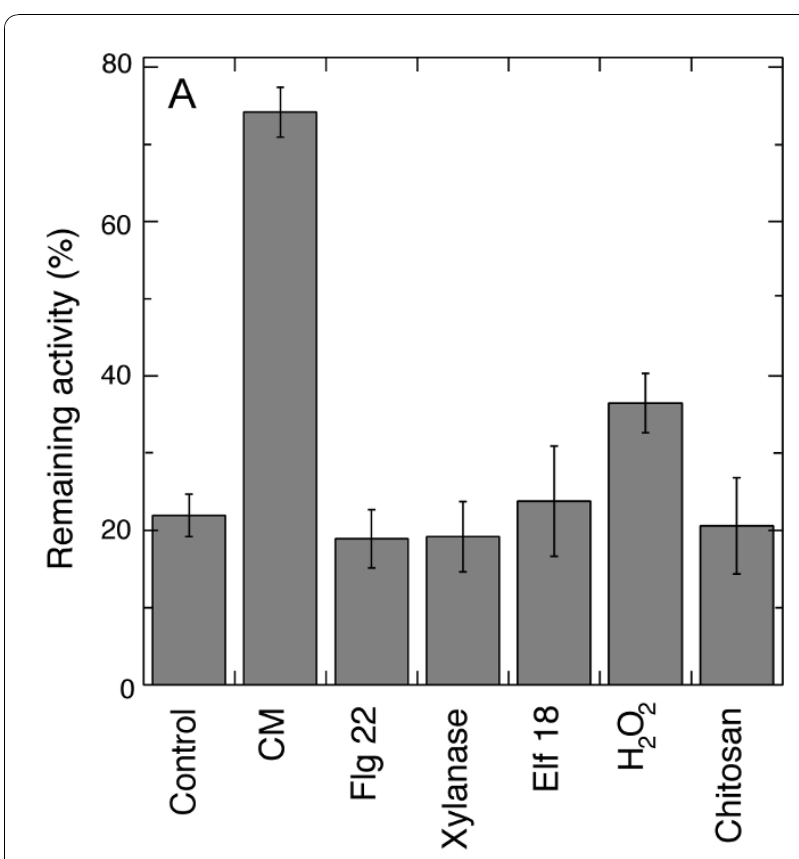

Figure 5 Resistance to alamethicin after preincubation of tobacco cells with known plant defence elicitors. Resistance was measured as per cent of respiration rate remaining after $10 \mathrm{~min}$ incubation with $20 \mathrm{\mu g} \mathrm{ml}^{-1}$ alamethicin compared to the initial rate. Data points are averages of three to five measurements and error bars represents SE.

examined gave an alamethicin resistance in the vicinity of that attained after CM treatment (Figure 4). In addition, cells were incubated with a low level $\left(1 \mu \mathrm{g} \mathrm{ml}^{-1}\right)$ of alamethicin during $4 \mathrm{~h}$ to find out if alamethicin by itself could elicit a resistance to further exposure. However, no difference in remaining respiration after regular alamethicin permeabilisation was evident $(24 \pm 7 \%$ in alamethicin-treated cells as compared to $22 \pm 7 \%$ for the control cells).

\section{Alamethicin resistance develops independently of protein synthesis and membrane depolarisation}

It could not be excluded that the CM-treatment induced a plasma membrane depolarisation sufficient to slow down the permeabilisation process or change the amount of alamethicin needed. Therefore, we tested the effect on alamethicin permeabilisation by the protonophore FCCP, which depolarises the transmembrane potential to the diffusion potential in maize roots [38] and abolishes adenylate control of respiration in tobacco cells [39]. As expected, FCCP activated respiration in both control and CM-treated cells, but alamethicin-permeabilisation of control cells was unaffected by the FCCP (Figure 6). Consistently, CM-treated cells were similarly resistant to alamethicin in the presence of FCCP (Figure 6A) as in its absence (Figure 6B, Control). 

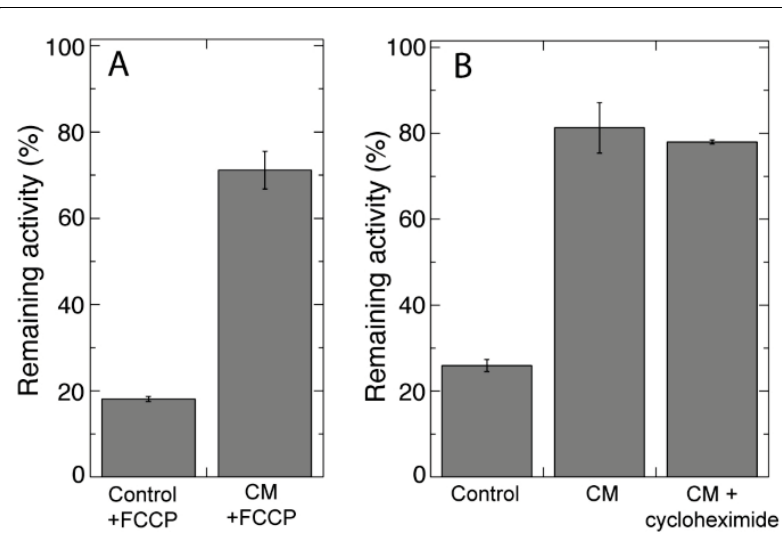

Figure 6 The effect of the uncoupler FCCP (A) and protein synthesis inhibitor cycloheximide (B) on the $\mathrm{CM}$-induced alamethicin resistance of tobacco cells. Resistance was measured as per cent of respiration rate remaining after 10 min incubation

with $20 \mathrm{\mu g} \mathrm{ml}^{-1}$ alamethicin compared to the initial rate. Average of two independent experiments are shown with error bars representing SD. FCCP was added just before alamethicin addition, whereas cycloheximide was added before CM treatment (as described in Methods). The respiration increased $1.6 \pm 0.1$ and $1.7 \pm$ 0.4 times in control and CM-treated cells, respectively, by the addition of FCCP, showing that respiration in the cell cultures became equally uncoupled from ATP synthesis.

We then investigated whether the alamethicin resistance of the tobacco cell cultures involved de novo protein synthesis. The presence of the protein synthesis inhibitor cycloheximide prior to and during incubation with CM did not affect the magnitude of alamethicin resistance (Figure 6B). This indicates that posttranslational changes are sufficient for induction of alamethicin resistance.

\section{CM treatment results in distinct plasma membrane lipid profile alterations}

As mentioned, alamethicin permeabilisation depends on membrane lipid composition in artificial systems [21]. This suggests that the resistance induced by cellulase seen here with tobacco cells, could be caused by changes in the membrane lipids. Plasma membranes were therefore isolated from control cells and CM-treated cells (Additional file 2). The total amount of membrane lipid fatty acids per protein increased more than $30 \%$ in plasma membranes of CM-treated cells compared to control (Figure 7). The sterol/protein ratio did not change, which means that the ratio of sterol to fatty acid decreased. The main sterols found in the plasma membrane of both control and enzyme-treated cells were campesterol, stigmasterol and $\beta$-sitosterol (Additional file 3). No changes in the relative amounts of the individual sterols were observed (Additional file 3). The ratio of acetylated sterol glycosides compared to free sterol, decreased from $0.39 \pm 0.03$ in control to $0.32 \pm$ 0.03 for CM-treated samples.

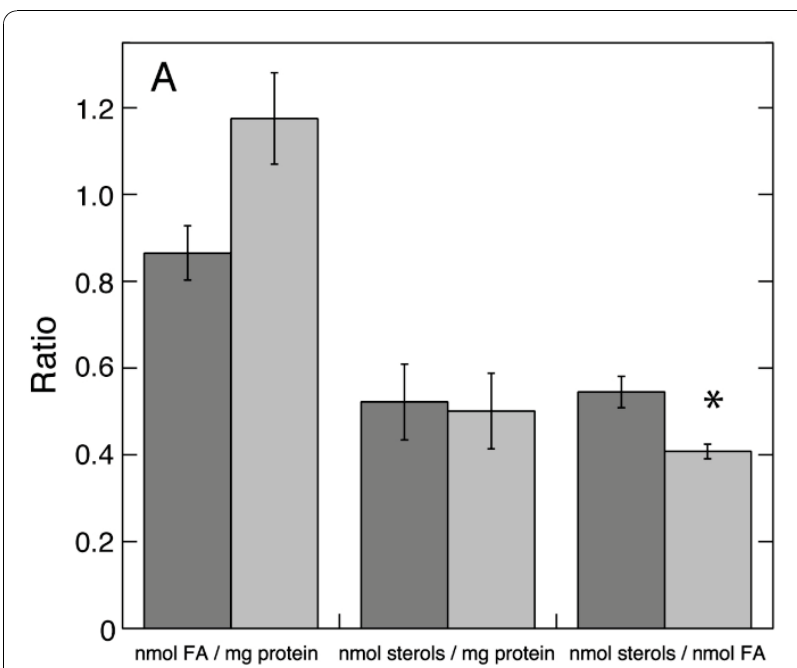

Figure 7 Protein, fatty acid and sterol ratios in plasma membranes isolated from control and CM-treated cells. Dark grey bars, control cells; light grey bars, CM-treated cells. Values used are averages of two plasma membrane preparations and error bars denote SD.

Differences were found in the amounts of plasma membrane phospholipids between control and CM-treated cells. Figure 8A shows that the most prominent change was a drastic lowering in phosphatidylserine and phosphatidylinositol (PS+PI) after CM-treatment. In contrast, we observed an increase in phosphatidylethanolamine (PE) detected together with phosphatidylglycerol (PG), but PE constituting at least $95 \%$ of the sum (results not shown). The responses to $\mathrm{CM}$ treatment for $\mathrm{PS}+\mathrm{PI}$ and PE+PG were significantly different $(\mathrm{p}<0.05)$. PS and PI are negatively charged phospholipids (at neutral pHs) as are phosphatidic acid (PA) and PG, whereas $\mathrm{PE}$ and phosphatidylcholine (PC) are zwitterionic and net uncharged molecules. Similar changes were not seen in the microsomal fractions, from which the plasma membranes were isolated (results not shown). The most common membrane lipid fatty acid in the plasma membrane of both control and CM-treated cells was 18:2 (linoleic acid) followed by 16:0 (palmitic acid; Figure $8 \mathrm{~B})$. No large changes in fatty acid species were induced by $\mathrm{CM}$ treatment except possibly for a CM-induced drop in 20:0 (arachidic acid). A small decrease in saturation was found in the CM-treated cells, i.e., the ratio between saturated and unsaturated fatty acid corresponded to $0.63 \pm 0.05$ in control membranes compared to $0.55 \pm 0.04 \%$ in membranes from CM-treated cells.

\section{Discussion}

Biocontrol fungi such as $T$. viride are known to induce systemic resistance, ISR, and prime their host plants to become more resistant to future attack from pathogenic 

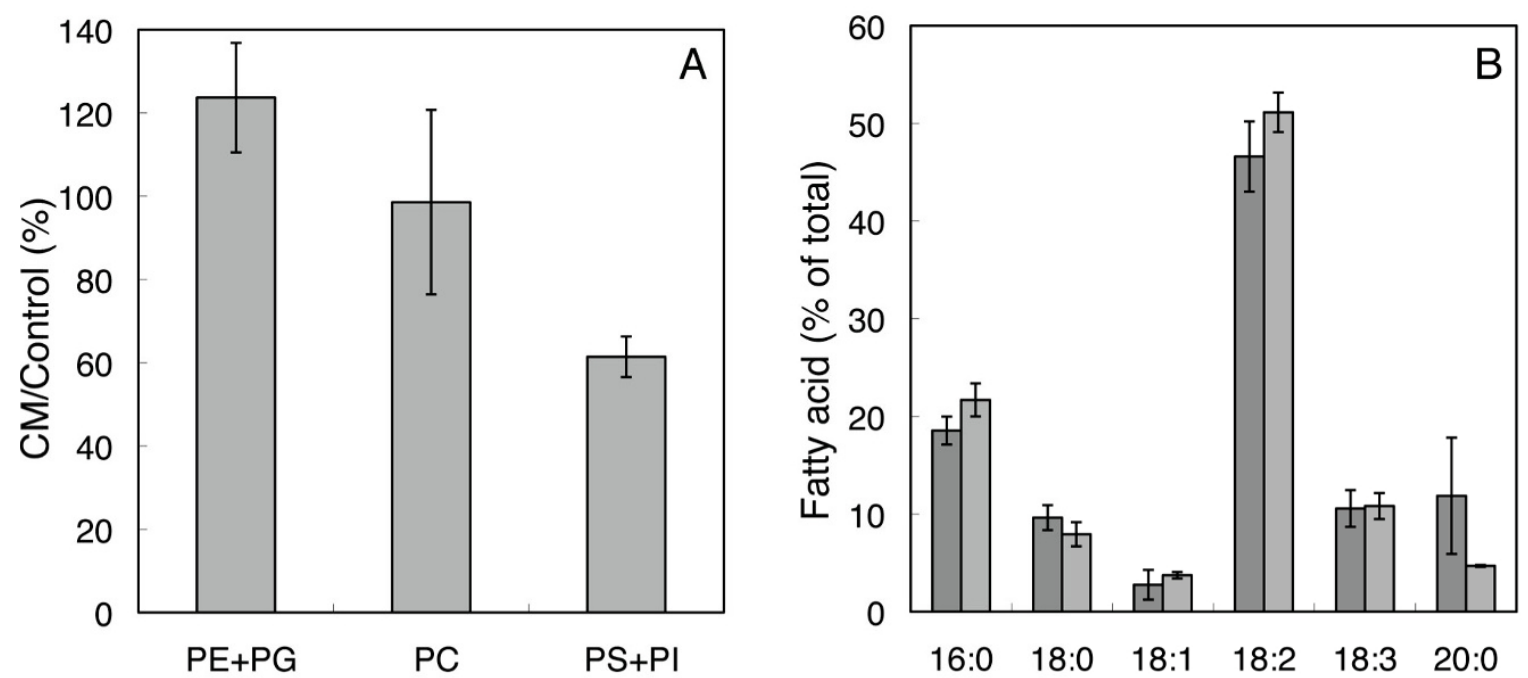

Figure 8 Phospholipid analysis of tobacco cell plasma membranes. (A) Percents of different phospholipids of plasma membranes from CMtreated cells relative to control cells. The CM/Control ratio for PS+PI was significantly different from that for PE+PG $(p<0.05)$. (B) Fatty acid composition of plasma membranes isolated from control and CM-treated cells. Dark grey bars, control cells; light grey bars, CM-treated cells. Values used are averages of two plasma membrane preparations and error bars denote SD.

microorganisms $[9,40]$. The transcriptional changes related to ISR are usually quite modest compared to systemic acquired resistance, SAR [41]. We here found that treatment of tobacco cells with $T$. viride cellulase resulted in posttranslational changes leading to altered membrane properties and alamethicin resistance. To the best of our knowledge, the presented data are the first to show that resistance to permeabilisation by the peptaibol alamethicin can be induced in any eukaryote. Interestingly, cell wall degrading enzymes and peptaibols from $T$. harzanium synergistically prevented spore germination and hyphal growth of Botrytis cinerea [42]. Thus, synergies that are harmful to one system (Trichoderma on pathogen) can be protective in another system (Trichoderma on plant), which favours a successful symbiotic relation between Trichoderma and the plant.

The alamethicin resistance observed was mainly elicited by the enzymatic activity of $T$. viride cellulase. This is strongly indicated by the reduction in elicited resistance by heat inactivation and by the presence of the cellulase inhibitor cellobiose. Further, the effect of inhibitors excludes the possibility of alamethicin resistance being elicited by any of the small known contaminants of most cellulase extracts. Shortening the enzyme incubation to $20 \mathrm{~min}$ followed by a post-incubation in Control medium alone (until the same total of $4 \mathrm{~h}$ had passed) did not reduce the alamethicin resistance induced. This indicates that the cellulase elicits the resistance during the first part of the incubation and that no further stimulus is required, but that it takes a certain time for the response to develop in the plant cell. After these treatments, no visual changes could be observed by light microscopy, indicating that only a limited cell wall digestion had taken place. Interestingly, the observed resistance displays some specificity for $T$. viride cellulases since the effect was neither seen upon incubation with a cellulase mixture from $T$. reesei nor by hemicellulases of the same fungus (Figure 5 Table 3). The presence of a cellulose-binding module (frequently carried by cellulases) did not induce resistance, consistent with the inactivation and inhibition studies showing that an active enzyme was needed (Figure 1 Figure 4).

It could be argued that the resistance observed here is a part of a general defence response to cell wall degradation, intended to increase the robustness of the plasma membrane in anticipation of a fungal or bacterial attack reaching through the cell wall. It has earlier been reported that cellulase treatment can evoke defence responses, e.g., increases in the stress-related phytoalexin capsidiol $[43,44]$ as well as the production of volatile compounds $[45,46]$. Xylanase, which can degrade the xylan of the cell wall hemicelluloses represents a threat to cell integrity similar to that posed by cellulase $[47,48]$. However, in contrast to the eliciting effect of cellulase in our experiments, xylanase does not need to be enzymatically active to elicit defence responses in tobacco [49]. Also, the difference in mode of elicitation is consistent with the inability of xylanase to elicit alamethicin resistance.

If alamethicin resistance were part of a general response to pathogen attack it would be reasonable to assume that many common plant elicitors mediated a 
similar response. The acetylated chitin derivate chitosan is able to elicit a large range of plant defensive responses, including HR, SAR, oxidative burst and callose deposition [50], yet we could not detect a significant difference in alamethicin resistance. Similarly, with the PAMPs flg 22 [51] and elf 18 [52], no elicitation of alamethicin resistance could be observed, despite their ability to trigger innate immunity. Finally, adding catalase to cells during CM did not prevent the elicitation of resistance (Additional file 2). This indicates that the somewhat increased resistance observed after $\mathrm{H}_{2} \mathrm{O}_{2}$ incubation is not due to $\mathrm{H}_{2} \mathrm{O}_{2}$ being a putative intermediate in the cellulase-initiated signalling cascade. Instead, the presence of $\mathrm{H}_{2} \mathrm{O}_{2}$ can lead to rapid crosslinking of the cell wall proteins [53]. The decrease in permeability of the cell wall after such cross-linking may be the reason for the moderate alamethicin resistance after $\mathrm{H}_{2} \mathrm{O}_{2}$ incubation (Figure 5). In any case, this resistance at the cell wall level cannot explain the cellulaseinduced alamethicin resistance, since also protoplasts devoid of cell wall were resistant to alamethicin.

Rather, the alamethicin resistance could be compared to classical R-gene-induced resistance in the sense that both might counteract pore formation activities of successful pathogens and beneficial microorganisms. Instead of manipulating the consequences of pores by deactivating the pathogen effectors that are transported through them, as is characteristic to R gene-mediated resistance, the alamethicin resistance decreases the possibility for pores to be formed.

Analyses conducted with artificial lipid bilayers have suggested that alamethicin needs to be delivered from the compartment with the net positive electric potential in order to be inserted and form pores in membranes [21]. Experimental data on biological systems are in line with this, i.e., the vacuole (which has a positive transmembrane potential) in tobacco cells was left intact under conditions when other membranes were permeabilised [26]. Upon cellulase treatment, the transmembrane potential of Medicago sativa root hairs was depolarised to ca $-50 \mathrm{mV}$ [54], i.e., to what probably would be the diffusion potential [55]. However, for the resistance development described here, transmembrane potential changes could be ruled out as important since no effect was obtained by the protonophore FCCP (Figure 6), an agent shown to depolarise the transmembrane potential in roots to the diffusion potential [38]. Also, protein synthesis was not needed for the process (Figure 6), showing that the resistance depended on modifications performed by pre-existing enzymes or structures. Cell wall modifications induced by the action of $T$. viride cellulase may result in both chemical and mechanical signals reaching the plant cell. Cellodextrins $(\beta-1,4$ glucose oligomers), i.e., the predominant breakdown products of cellulose, induced pathogen responses in Vitis vinifera [56]. On the other hand, homologues of prokaryotic and eukaryotic mechanosensitive channels were recently identified in A. thaliana [57], and an existence of mechanosensing signalling also in plants has recently been suggested [58]. However, the lack of effect by xylanase in our experiments (Figure 5) and the quite small effect induced by macerozyme (Table 2) shows that if the signal is mechanical, it cannot operate simply through the degradation of classical matrix polysaccharides.

Peptide-induced pore formation depends on membrane lipid species and lipid/peptide ratio [31]. We found that the sterol to membrane lipid fatty acid ratio (Figure 7), the fraction of PS+PI (Figure 8) and the acyl group 20:0 decreased as a consequence of enzyme treatment. Our analyses were performed with cells that still were indistinguishable from untreated cells with regard to shape (Additional file 1), but when substantial alamethicin resistance could be detected. Therefore, the changes in lipid composition seen probably reflect the defence induced against $T$. viride, whereas the degradative changes often associated with complete protoplastation [59-61] are kept at a minimum. This also agrees with that strains of Staphylococcus aureus, Enterococcus faecalis and Bacillus cereus with a five-fold increased resistance to alamethicin permeabilisation $\left(\mathrm{IC}_{50}\right.$ of 2-5.5 $\mu \mathrm{g} \mathrm{ml}{ }^{-1}$ alamethicin in sensitive and 9.5 to $29 \mu \mathrm{g} \mathrm{ml}^{-1}$ in resistant strains, respectively), showed altered membrane lipid composition as well as lower alamethicin association to vesicles prepared from membrane extracts [62].

The CM-induced changes in phospholipids and their corresponding fatty acids (Figure 7 Figure 8), suggest that the physical properties of the plasma membrane were altered, possibly sufficient to affect alamethicin insertion and pore formation. This agrees with that the conductance through pores made by the antimicrobial cationic peptide gaegurin 4 was larger in planar bilayers made of PE, PC and PS (80:10:10) compared to membranes composed of only PE and PC (80:20) [63]. A role of sterols with respect to alamethicin channel activity was shown with artificial membranes, i.e., the presence of cholesterol increased the duration of the alamethicin pore in its open state, indicating a more efficient use of created pores, while the critical concentration of alamethicin needed for pore formation increased $[64,65]$. Oligomerisation and pore formation by Vibrio cholerae cytolysin also depended on the presence of cholesterol [66]. With gaegurin 4 [63], inclusion of cholesterol in planar lipid membranes acted opposite to PS, i.e., it prevented channel formation. This deviates from the association of increased alamethicin resistance to decreased sterol levels (relative to fatty acids) observed with tobacco cells (Figure 7). However, the hydrophobic 
alamethicin forms pores that traverse the membrane through its hydrophobic part, whereas cationic peptides such as gaegurin 4 form pores in the membrane where peptide and membrane lipid headgroups are exposed to the inner of the pore [67]. Besides, the presence of proteins in biological membranes adds another degree of complexity, making direct comparisons between peptide types difficult.

Large differences in lipid composition were used in the above investigations of alamethicin pore formation with artificial membranes. This might speak against direct comparisons with the smaller differences found for the tobacco plasma membrane here, also since the artificial membranes do not contain proteins as do biological membranes. However, effector-induced changes in membrane phospholipids and sterols of similar magnitudes as we found with tobacco lead to changes in membrane stability with isolated plasma membranes from oat roots [68] and S. cerevisiae [69] as seen by changes in transversal bilayer diffusion.

Another important property of especially the phospholipids is their charge, with $\mathrm{PC}$ and PE being uncharged and PA, PI, PS and PG being negatively charged. The charges of the lipid head groups and the membrane proteins will cause a local surface charge which will affect the attraction of ions to approach the membrane, and also modulate the spacing of lipids. In our experiments, we found that CM treatment resulted in lower PM-associated PS+PI and higher PE (+PG) compared to control cells (Figure 8A). Even though the surface charges depend also on e.g., proteins and the phospholipid distribution between the respective plasma membrane leaflets, the results suggest that overall surface charge of the plasma membrane may be lower in CM-treated cells compared to control cells. With artificial membranes, lower surface charge result in less alamethicin inserted [70].

\section{Conclusions}

T. viride cellulase treatment made tobacco cells resistant to permeabilisation by alamethicin. Several changes in the lipid composition of plasma membrane were found, suggesting a change in membrane properties. It is conceivable that the defence response elicited by $T$. viride cellulase makes the tobacco plasma membranes resistant to alamethicin by acting on membrane properties that are needed for alamethicin insertion. In nature, plant roots are likely to encounter cellulase and alamethicin at the same time, as they are both secreted by $T$. viride. Plant cells should therefore be more sensitive at the site of first encounter during the time needed for resistance induction. However, this is not lethal, and at later stages, when a signal from the partially degraded cell wall (chemical or mechanical) have led to altered membrane properties, the plant root will have built up its resistance to alamethicin. This renders the plant root insensitive to alamethicin at concentrations that might inhibit or kill nearby microbes. The shift seen here in sensitivity to alamethicin (Figure 3 ) is fully in accordance with such an explanation. These findings therefore provide a model of how a beneficial microorganism can protect its symbiotic plant counterpart from pore forming molecules that it secretes to attack pathogens in the surroundings.

\section{Methods}

Plant material

Nicotiana tabacum BY-2 cells were grown on a rotary shaker at $125 \mathrm{rpm}$ in constant darkness at $24^{\circ} \mathrm{C}$, and subcultured every seven days as described [26]. The cells were harvested for experiments on the fourth day after subculture, during the exponential growth phase (300 - $450 \mathrm{mg}$ fresh weight cells per ml medium).

\section{Treatments of BY-2 cells for oxygen electrode measurements and microscopy}

Unless otherwise denoted, tobacco BY-2 cells were incubated for $4 \mathrm{~h}$ in a Control medium $(0.35 \mathrm{M}$ mannitol, pH 5.0) or CM medium, i.e., Control medium supplemented with enzymes ( $1 \%$ cellulase "Onozuka" RS (Yakult Honsha co., Ltd., Japan, if not otherwise stated) and $0.1 \%$ macerozyme (Yakult Honsha co., Ltd., Japan). In some experiments, the concentrations of cellulase and macerozyme were varied, and treatments were also made where the cellulase and or macerozyme was inactivated by boiling prior to addition. In other cases, cells were incubated in $\mathrm{CM}$ medium for $20 \mathrm{~min}$ and then pelleted and transferred to Control medium and incubated for another $220 \mathrm{~min}$. Other treatments were: either $0.1 \mu \mathrm{g} \mathrm{ml}^{-1}$ alamethicin, $100 \mu \mathrm{g} \mathrm{ml}^{-1}$ xylanase from $T$. viride, $1 \mu \mathrm{M}$ elf18 (SKEKFERTKPHVNVGTIS; Caslo Laboratory ApS, Denmark), $1 \mu \mathrm{M}$ flg22 (QRLSTGSRINSAKDDAAGLQIA; Caslo Laboratory ApS, Denmark), $1 \mathrm{mM} \mathrm{H}_{2} \mathrm{O}_{2}, 10 \mu \mathrm{g} \mathrm{ml}^{-1}$ chitosan, $0.3 \mathrm{U}$ $\mathrm{ml}^{-1}$ Celluclast $1.5 \mathrm{~L}$ (a mixture of Trichoderma reesei cellulases and other plant cell wall degradative enzymes from Novozymes, Denmark) [71], $0.3 \mathrm{U} \mathrm{ml}^{-1}$ TrCelB endoglucanase catalytic module [72], and $0.3 \mathrm{U} \mathrm{ml}^{-1}$ TrMann5A endomannanase (carrying a cellulose-binding module [73]), all in Control medium. Combinations of $0.1 \mathrm{M}$ cellobiose, $0.1 \mathrm{M}$ glucose and mannitol to a total concentration of $0.35 \mathrm{M}$ were added in experiments where the inhibition of cellulase was tested. Catalase was used to a final concentration of $192 \mathrm{U} \mathrm{ml}^{-1}$. This concentration is sufficient to inhibit $\mathrm{H}_{2} \mathrm{O}_{2}$ mediated apoplastic peroxidase cycles [26,74]. In one experiment $80 \mu \mathrm{M}$ cycloheximide was included with the enzyme treatment, as well as $1 \mathrm{~h}$ prior to enzyme 
addition. This concentration is sufficient to inhibit inducible processes in tobacco cell suspensions [75]. In another experiment, $4 \mu \mathrm{M}$ FCCP was added just before alamethicin addition. All treatments were performed at room temperature on a rotary shaker at $70 \mathrm{rpm}$.

\section{Oxygen electrode measurements}

After treatments, the BY-2 cells were diluted in a measuring medium (20 mM HEPES, $60 \mathrm{mM}$ MES, $300 \mathrm{mM}$ mannitol, $1 \mathrm{mM} \mathrm{MgCl}$ and $1 \mathrm{mM}$ EGTA, pH 7.5) to $40 \mathrm{mg}(\mathrm{FW}) \mathrm{ml}^{-1}$ (i.e., ca 10 times dilution) and oxygen consumption was measured using a $1 \mathrm{ml}$ Clark Oxygen Electrode (Rank Brothers, UK). After initial measurements of cellular respiration, alamethicin (SigmaAldrich, Germany) was added from a stock solution (20 mg ml $\mathrm{m}^{-1}$ in $60 \%$ ethanol) and respiration was measured for an additional $10 \mathrm{~min}$. Unless otherwise stated, a concentration of $20 \mu \mathrm{g} \mathrm{ml}^{-1}$ of alamethicin was used. Resistance against permeabilisation was determined as the ratio between the slope $10 \mathrm{~min}$ after alamethicin addition and the initial slope (see Figure 1).

\section{Microscopy}

BY-2 cells were treated with Control medium or CM medium for $3 \mathrm{~h}$ (Additional file 1), or with Control medium for $4 \mathrm{~h}$ respectively with $\mathrm{CM}$ medium for $20 \mathrm{~min}$ followed by $220 \mathrm{~min}$ with Control medium (Figure 2). Before incubation with dyes, cells were diluted to $40 \mathrm{mg}(\mathrm{FW}) \mathrm{ml}^{-1}$ (i.e., ca 10 times dilution) in measuring medium (see above). For propidium iodide staining, cells were incubated with $20 \mu \mathrm{g} \mathrm{ml}^{-1}$ of alamethicin for $10 \mathrm{~min}$ and $1.5 \mu \mathrm{M}$ propidium iodide (Invitrogen, Sweden) was added during the last 5 min of the alamethicin incubation.

Fluorescence microscopy was performed using a G2A-filter (excitation at $510-560 \mathrm{~nm}$, emission above 590 $\mathrm{nm}$ ) in a Nikon-Optiphot-2 microscope (Nikon Corporation, Japan). As a reference, a bright field transmission microscopy picture was taken.

Confocal microscopy images were collected using a Zeiss LSM 510 (Zeiss, Germany).

\section{Plasma membrane purification}

Membrane fractions were prepared from cell cultures treated with Control or CM media. The alamethicin resistance of the CM-treated cells was measured regularly using oxygen electrode respiration measurements (see above) and cells were harvested for fractionation when the alamethicin resistance was above $60 \%$.

Cell cultures (ca $50 \mathrm{~g}$ per treatment) were suspended in extraction buffer $(50 \mathrm{mM}$ MOPS/KOH, $\mathrm{pH} 7.5$, $5 \mathrm{mM}$ EDTA, $330 \mathrm{mM}$ sucrose, $5 \mathrm{mM}$ ascorbic acid, $3 \mathrm{mM}$ DTT, $0.6 \%(\mathrm{w} / \mathrm{v})$ polyvinyl polypyrrolidone) and homogenized using a mixer fitted with razorblades
(Braun). Extracts were filtered through a $150 \mu \mathrm{m}$ net and centrifuged at $7,200 \times \mathrm{g}$ for $15 \mathrm{~min}$ at $4^{\circ} \mathrm{C}$. The supernatants were centrifuged at 40,000 $\times \mathrm{g}$ for $1 \mathrm{~h}$ at $4^{\circ} \mathrm{C}$ to pellet the microsomal fraction (MF). Plasma membranes (PM) and intracellular membranes (ICM) were purified from the microsomal fraction by partitioning in an aqueous polymer two-phase system $[76,77]$. A phase system of the following composition was used: $6.0 \%(\mathrm{w} / \mathrm{w})$ Dextran T 500, 6.0\% (w/w) polyethylene glycol 4000, $330 \mathrm{mM}$ sucrose, $5 \mathrm{mM}$ potassium phosphate (pH 7.8) and $2 \mathrm{mM} \mathrm{KCl}$. After three partitioning steps, the fractions (PM, ICM and MF) were diluted in 250 $\mathrm{mM}$ mannitol, $10 \mathrm{mM}$ HEPES/KOH, $\mathrm{pH} 7.5$ ) and pelleted by centrifugation at $100,000 \times \mathrm{g}$ for $1 \mathrm{~h}$ at $4^{\circ} \mathrm{C}$. Samples were resuspended in the same medium and were stored at $-80{ }^{\circ} \mathrm{C}$ until use.

\section{Assays}

The degree of purification of plasma membranes from microsomal fractions was established by comparing callose synthesis (GSII) and cytochrome $c$ oxidase activity in plasma membrane and intracellular membrane fractions to that of the original microsomal fraction. Callose synthesis and cytochrome c oxidase activity was measured according to [78] and [79] respectively. Protein was determined according to Bearden [80]. To ensure that the membrane fractions obtained were of similar purity, markers for plasma membrane and mitochondria were analysed with these membrane fractions. The enrichment of callose synthase activity (plasma membrane marker) and depletion of cytochrome $c$ oxidase activity (marker for the mitochondrial inner membrane) in the respective plasma membrane fraction were relatively similar (Additional file 4) showing that they were useful for comparative studies. The enrichments obtained agree well with earlier obtained data on plasma membrane purification [76,77]. MAP kinase activity was measured according to [81].

\section{Lipid analyses}

Lipids were extracted according to Sommarin and Sandelius [82] and fractionated into neutral lipids, glycolipids and phospholipids by solid phase extraction (SPE) as described [83]. For quantification of sterols and phospholipids, internal standards were added to the lipid extracts before SPE fractionation. Sterols were analyzed after conversion to trimethylsilyl (TMS)-ethers by gas liquid chromatography (GLC) using the same setup as in described [83]. $\beta$-cholestanol and di17:0-phosphatidylcholine were used as internal standards for sterol and phospholipids, respectively. Glycolipids were analyzed by high pressure liquid chromatography (HPLC) equipped with a light scattering detector as previously described [83] and quantified using standard curves of authentic 
lipid standards. Fatty acid methyl esters (FAME) were produced by base catalysis of sodium-methoxide in methanol [84] and quantified on a GLC, as previously described [83]. Diheptadecanoylphosphatidylcholine was used as internal standard. Thin layer chromatography (TLC) was performed using Si60 TLC plates (VWR International, Germany) and lipids were identified by co-chromatography with authentic lipid standards (Sigma-Aldrich, USA). TLC plates were developed in $\mathrm{CHCl}_{3}: \mathrm{MeOH}$ :acetic acid:water $(85: 15: 10: 3.5)$ and the lipids were visualized by charring [85] or dichlorofluorescein treatment [86] Phospholipid proportions were quantified by densitometry using Syngene Bio imaging system (UK) and accompanying software.

\section{Additional material}

\section{Additional file 1: Confocal transmission images of tobacco cells.}

Images are taken after $3 \mathrm{~h}$ of treatment with Control medium (A), or 20 min with CM medium followed by 160 min with Control medium (B). (C, D) Magnified squared sections of $A$ and $B$, respectively. The bar denotes $50 \mu \mathrm{m}$ and is valid also for $\mathrm{B}$

Additional file 2: Effect of preincubation of tobacco cells with catalase on resistance to alamethicin. Resistance was measured as per cent of respiration rate remaining after 10 min incubation with $20 \mathrm{\mu g} \mathrm{ml}^{-}$ 1 alamethicin compared to the initial rate.

Additional file 3: Sterol analysis of tobacco cell plasma membranes isolated from control and CM-treated cells.

Additional file 4: Membrane marker analysis of fractions from control and CM-treated cells.

\section{Abbreviations}

CM: cellulase and macerozyme; FCCP: carbonylcyanide 4(-triflouromethoxy) phenylhydrazone; PA: phosphatidic acid; PE: phospatidylethanolamine; PG: phosphatidylglycerol; PI: phosphatidylinositol; PS: phosphatidylserine.

\section{Acknowledgements}

The authors are thankful to Lena Carlsson for skilful technical assistance and Peter Ekström for help with the confocal microscopy. This investigation was made possible through financial support from the Swedish Science Research Council, Swedish Council for Forestry and Agricultural Research (FORMAS) and Carl Trygger's Science Foundation.

\section{Author details \\ 'Department of Biology, Lund University, Sölvegatan 35, SE-223 62 LUND, Sweden. ${ }^{2}$ Plant Biology Department, Michigan State University, East Lansing, 48824, MI, USA. ${ }^{3}$ Department of Plant and Environmental Sciences, Göteborg University, P.O. Box 461, SE-405 30 Göteborg, Sweden. ${ }^{4}$ Department of Biochemistry, P.O. Box 124, SE-221 00 Lund, Sweden. ${ }^{5}$ Department of Plant Protection Biology, Swedish Agricultural University, P.O. Box 102, SE-230 53 Alnarp, Sweden.}

\section{Authors' contributions}

SW, AR and MA conceived the study and planned the majority of the experiments. MA conducted all the experiments. HT and ASS took part in the lipid analyses and the interpretation of the results from these, HS with the experiments with glucanases and EA with the elicitors. SW and MA wrote the manuscript with substantial contribution also from AGR. All authors read, commented and approved the manuscript.

Received: 9 September 2010 Accepted: 14 December 2010 Published: 14 December 2010
References

1. Hou S, Yang Y, Zhou J-M: The multilevel and dynamic interplay between plant and pathogen. Plant Signal Behav 2009, 4:283-293.

2. Buttner $D$, Bonas U: Who comes first? How plant pathogenic bacteria orchestrate type III secretion. Curr Opin Microbiol 2006, 9:193-200.

3. Jones JD, Dangl JL: The plant immune system. Nature 2006, 444:323-329.

4. Wei ZM, Laby RJ, Zumoff CH, Bauer DW, He SY, Collmer A, Beer SV: Harpin, elicitor of the hypersensitive response produced by the plant pathogen Erwinia amylovora. Science 1992, 257:85-88.

5. Keen NT, Tamaki S, Kobayashi D, Gerhold D, Stayton M, Shen H, Gold S, Lorang J, Thordal-Christensen $H$, Dahlbeck D, et al: Bacteria expressing avirulence Gene D produce a specific elicitor of the soybean hypersensitive reaction. Mol Plant Microbe Interact 1990, 3:112-121.

6. Agrios GN: Plant Pathology. Fifth revised edition. London: Elsevier Academic Press; 2005.

7. Benitez T, Rincon AM, Limon MC, Codon AC: Biocontrol mechanisms of Trichoderma strains. Int Microbiol 2004, 7:249-260.

8. Harman GE, Howell CR, Viterbo A, Chet I, Lorito M: Trichoderma speciesopportunistic, avirulent plant symbionts. Nature Rev Microbiol 2004, 2:43-56.

9. Shoresh M, Harman GE, Mastouri F: Induced systemic resistance and plant responses to fungal biocontrol agents. Annu Rev Phytopathol 2010, 48:1-23.

10. Vinale F, Sivasithamparam K, Ghisalberti EL, Marra R, Woo SL, Lorito M: Trichoderma-plant-pathogen interactions. Soil Biol Biochem 2008, 40:1-10.

11. Hanson LE, Howell CR: Elicitors of plant defense responses from biocontrol strains of Trichoderma virens. Phytopathol 2004, 94:171-176.

12. Djonovic S, Vargas WA, Kolomiets MV, Horndeski M, Wiest A, Kenerley CM: A proteinaceous elicitor $\mathrm{Sm} 1$ from the beneficial fungus Trichoderma viride is required for induced systemic resistance in maize. Plant Physiol 2007, 145:875-889.

13. Viterbo A, Wiest A, Brotman Y, Chet I, Kenerley C: The 18mer peptaibols from Trichoderma virens elicit plant defence responses. Molecular Plant Pathology 2007, 8:737-746.

14. Chen F, D'Auria JC, Tholl D, Ross JR, Gershenzon J, Noel JP, Pichersky E: An Arabidopsis thaliana gene for methylsalicylate biosynthesis, identified by a biochemical genomics approach, has a role in defense. Plant J 2003, 36:577-588.

15. Engelberth J, Koch T, Schuler G, Bachmann N, Rechtenbach J, Boland W: lon channel-forming alamethicin is a potent elicitor of volatile biosynthesis and tendril coiling. Cross talk between jasmonate and salicylate signaling in lima bean. Plant Physiol 2001, 125:369-377.

16. Maischak H, Zimmermann MR, Felle HH, Boland W, Mithöfer A: Alamethicin-induced electrical long distance signaling in plants. Plant Signal Behav 2010, 5:988-990.

17. Rippa S, Eid M, Formaggio F, Toniolo C, Beven L: Hypersensitive-like response to the pore-former peptaibol alamethicin in Arabidopsis thaliana. Chembiochem 2010, 11:2042-2049.

18. Krause C, Kirschbaum J, Jung G, Bruckner H: Sequence diversity of the peptaibol antibiotic suzukacillin-A from the mold Trichoderma viride. $J$ Pept Sci 2006, 12:321-327.

19. Szekeres A, Leitgeb B, Kredics L, Antal Z, Hatvani L, Manczinger L, Vagvolgyi C: Peptaibols and related peptaibiotics of Trichoderma. A review. Acta Microbiol Immunol Hung 2005, 52:137-168.

20. Montesinos E: Antimicrobial peptides and plant disease control. Fems Microbiol Lett 2007, 270:1-11.

21. Cafiso DS: Alamethicin: a peptide model for voltage gating and proteinmembrane interactions. Annu Rev Biophys Biomol Struct 1994, 23:141-165.

22. Leitgeb B, Szekeres A, Manczinger L, Vagvolgyi C, Kredics L: The history of alamethicin: A review of the most extensively studied peptaibol. Chem Biodivers 2007, 4:1027-1051.

23. Meyer CE, Reusser F: A polypeptide antibacterial agent isolated from Trichoderma viride. Experientia 1967, 23:85-86.

24. Jen WC, Jones GA, Brewer D, Parkinson VO, Taylor A: The antibacterial activity of alamethicins and zervamicins. J Appl Bacterio/ 1987, 63:293-298.

25. Duclohier $\mathrm{H}$, Wroblewski $\mathrm{H}$ : Voltage-dependent pore formation and antimicrobial activity by alamethicin and analogues. J Membr Biol 2001 184:1-12.

26. Matic S, Geisler DA, Møller IM, Widell S, Rasmusson AG: Alamethicin permeabilizes the plasma membrane and mitochondria but not the 
tonoplast in tobacco (Nicotiana tabacum L. cv Bright Yellow) suspension cells. Biochem J 2005, 389:695-704.

27. Boheim G: Statistical analysis of alamethicin channels in black lipid membranes. J Membr Biol 1974, 19:277-303.

28. Johansson FI, Michalecka AM, Møller IM, Rasmusson AG: Oxidation and reduction of pyridine nucleotides in alamethicin-permeabilized plant mitochondria. Biochem J 2004, 380:193-202.

29. Aguilella VM, Bezrukov SM: Alamethicin channel conductance modified by lipid charge. Eur Biophys J 2001, 30:233-241.

30. Bezrukov SM, Rand RP, Vodyanoy I, Parsegian VA: Lipid packing stress and polypeptide aggregation: alamethicin channel probed by proton titration of lipid charge. Faraday Disc 1998, 173-183.

31. Heller WT, He K, Ludtke SJ, Harroun TA, Huang HW: Effect of changing the size of lipid headgroup on peptide insertion into membranes. Biophys $J$ 1997, 73:239-244.

32. Aidemark M, Andersson CJ, Rasmusson AG, Widell S: Regulation of callose synthase activity in situ in alamethicin-permeabilized Arabidopsis and tobacco suspension cells. BMC Plant Biol 2009, 9:27.

33. Beldman G, Searle-Van Leeuwen MF, Rombouts FM, Voragen FG: The cellulase of Trichoderma viride. Purification, characterization and comparison of all detectable endoglucanases, exoglucanases and $\beta$ glucosidases. Eur J Biochem 1985, 146:301-308.

34. Rapp P, Knobloch U, Wagner F: Repression of endo-1,4- $\beta$-glucanase formation in Penicillium janthinellum and product inhibition of Its 1,4- $\beta$ glucanases and cellobiases. J Bacteriol 1982, 149:783-786.

35. Woodward J, Wiseman A: Fungal and other $\beta$-D-glucosidases - Their properties and applications. Enzyme Microb Technol 1982, 4:73-79.

36. Bissett F, Sternberg D: Immobilization of Aspergillus $\beta$-glucosidase on chitosan. Appl Environ Microbiol 1978, 35:750-755.

37. Gong CS, Ladisch MR, Tsao GT: Cellobiase from Trichoderma viride: purification, properties, kinetics, and mechanism. Biotechnol Bioeng 1977, 19:959-981.

38. Ober ES, Sharp RE: Electrophysiological responses of maize roots to low water potentials: relationship to growth and ABA accumulation. J Exp Bot 2003, 54:813-824.

39. Vanlerberghe GC, Mcintosh L: Mitochondrial electron-transport regulation of nuclear gene-expression - Studies with the alternative oxidase gene of tobacco. Plant Physiol 1994, 105:867-874.

40. Van Wees SCM, Van der Ent S, Pieterse CMJ: Plant immune responses triggered by beneficial microbes. Curr Opin Plant Biol 2008, 11:443-448.

41. Van der Ent S, Van Wees SC, Pieterse CM: Jasmonate signaling in plant interactions with resistance-inducing beneficial microbes. Phytochem 2009, 70:1581-1588.

42. Schirmböck M, Lorito M, Wang YL, Hayes CK, Arisan-Atac I, Scala F, Harman GE, Kubicek CP: Parallel formation and synergism of hydrolytic enzymes and peptaibol antibiotics, molecular mechanisms involved in the antagonistic action of Trichoderma harzianum against phytopathogenic fungi. Appl Environ Microbiol 1994, 60:4364-4370.

43. Mialoundama AS, Heintz D, Debayle D, Rahier A, Camara B, Bouvier F: Abscisic acid negatively regulates elicitor-induced synthesis of capsidiol in wild tobacco. Plant Physiol 2009, 150:1556-1566.

44. Ma CJ: Cellulase elicitor induced accumulation of capsidiol in Capsicum annuum L. suspension cultures. Biotechnol Lett 2008, 30:961-965.

45. Moreau RA, Preisig CL: Lipid changes in tobacco cell suspensions following treatment with cellulase elicitor. Physiol Plant 1993, 87:7-13.

46. Piel J, Atzorn R, Gabler R, Kuhnemann F, Boland W: Cellulysin from the plant parasitic fungus Trichoderma viride elicits volatile biosynthesis in higher plants via the octadecanoid signalling cascade. FEBS Lett 1997, 416:143-148.

47. Lotan T, Fluhr R: Xylanase, a novel elicitor of pathogenesis-related proteins in tobacco, uses a non-ethylene pathway for induction. Plant Physiol 1990, 93:811-817.

48. Belien T, Van Campenhout S, Robben J, Volckaert G: Microbial endoxylanases: effective weapons to breach the plant cell-wall barrier or, rather, triggers of plant defense systems? Mol Plant Microbe Interact 2006, 19:1072-1081.

49. Enkerli J, Felix G, Boller T: The enzymatic activity of fungal xylanase is not necessary for its elicitor activity. Plant Physiol 1999, 121:391-397.

50. Iriti M, Faoro F: Chitosan as a MAMP, searching for a PRR. Plant Signal Behav 2009, 4:66-68.
51. Felix G, Duran JD, Volko S, Boller T: Plants have a sensitive perception system for the most conserved domain of bacterial flagellin. Plant $J$ 1999, 18:265-276.

52. Kunze G, Zipfel C, Robatzek S, Niehaus K, Boller T, Felix G: The $\mathbf{N}$ terminus of bacterial elongation factor Tu elicits innate immunity in Arabidopsis plants. Plant Cell 2004, 16:3496-3507.

53. Bradley DJ, Kjellbom P, Lamb CJ: Elicitor-induced and wound-induced oxidative cross-linking of a proline-rich plant cell wall protein - a novel, rapid defense response. Cell 1992, 70:21-30

54. Carden DE, Felle HH: The mode of action of cell wall-degrading enzymes and their interference with Nod factor signalling in Medicago sativa root hairs. Planta 2003, 216:993-1002.

55. Nicholls DG, Ferguson SJ: Bioenergetics 3. Academic Press, London; 2002.

56. Aziz A, Gauthier A, Bezler A, Poinssot B, Joubert JM, Pugin A, Heyraud A, Baillieul F: Elicitor and resistance-inducing activities of $\beta-1,4$ cellodextrins in grapevine, comparison with $\beta-1,3$ glucans and $\alpha-1,4$ oligogalacturonides. J Exp Bot 2007, 58:1463-1472.

57. Haswell ES, Peyronnet R, Barbier-Brygoo H, Meyerowitz EM, Frachisse JM: Two MscS homologs provide mechanosensitive channel activities in the Arabidopsis root. Curr Biol 2008, 18:730-734

58. Monshausen GB, Gilroy S: The exploring root - root growth responses to local environmental conditions. Curr Opin Plant Biol 2009, 12:766-772

59. Passaquet C, Teodorescuionescu N, Zuilyfodil Y, Thi ATP: Changes in fatty acid and lipid content in callus and protoplasts of Parthenocissus tricuspidata and Petunia hybrida during culture. Physiol Plant 1986, 67:211-216.

60. Kesselmeier J, Eichenberger W, Urban B: Sterols and sterylglycosides of oats (Avena sativa). Distribution in the leaf tissue and medium-induced glycosylation of sterols during protoplast isolation. Physiol Plant 1987, 610-616.

61. Hoischen C, Gura K, Luge C, Gumpert J: Lipid and fatty acid composition of cytoplasmic membranes from Streptomyces hygroscopicus and its stable protoplast-type L form. J Bacteriol 1997, 179:3430-3436.

62. Thippeswamy HS, Sood SK, Venkateswarlu R, Raj I: Membranes of five-fold alamethicin-resistant Staphylococcus aureus, Enterococcus faecalis and Bacillus cereus show decreased interactions with alamethicin due to changes in membrane fluidity and surface charge. Ann Microbiol 2009, 59:593-601.

63. Kim H, Lee BJ, Lee MH, Hong SG, Ryu PD: Mechanisms of selective antimicrobial activity of Gaegurin 4. Korean J Physiol Pha 2009, 13:39-47.

64. Latorre R, Donovan Jj: Modulation of alamethicin-induced conductance by membrane composition. Acta Physiol Scand 1980, , Suppl 481: 37-45.

65. Stankowski S, Schwarz UD, Schwarz G: Voltage-dependent pore activity of the peptide alamethicin correlated with incorporation in the membrane: salt and cholesterol effects. Biochim Biophys Acta 1988, 941:11-18.

66. Krasilnikov OV, Merzlyak PG, Lima VL, Zitzer AO, Valeva A, Yuldasheva LN: Pore formation by Vibrio cholerae cytolysin requires cholesterol in both monolayers of the target membrane. Biochimie 2007, 89:271-277.

67. Sato H, Feix JB: Peptide-membrane interactions and mechanisms of membrane destruction by amphipathic a-helical antimicrobial peptides. Biochim Biophys Acta 2006, 1758:1245-1256.

68. Berglund $\mathrm{AH}$, Larsson KE, Liljenberg CS: Permeability behaviour of lipid vesicles prepared from plant plasma membranes-impact of compositional changes. Biochim Biophys Acta 2004, 1682:11-17.

69. Pedroso N, Matias AC, Cyrne L, Antunes F, Borges C, Malho R, de

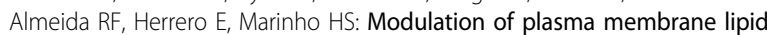
profile and microdomains by $\mathrm{H}_{2} \mathrm{O}_{2}$ in Saccharomyces cerevisiae. Free Rad Biol Med 2009, 46:289-298.

70. Chiriac R, Luchian T: $\mathrm{pH}$ modulation of transport properties of alamethicin oligomers inserted in zwitterionic-based artificial lipid membranes. Biophys Chem 2007, 130:139-147.

71. Alkasrawi M, Eriksson T, Börjesson J, Wingren A, Galbe M, Tjerneld F, Zacchi G: The effect of Tween-20 on simultaneous saccharification and fermentation of softwood to ethanol. Enzyme Microb Technol 2003, 33:71-78.

72. Eriksson T, Stals I, Collén A, Tjerneld F, Claeyssens M, Stålbrand H, Brumer H: Heterogeneity of homologously expressed Hypocrea jecorina (Trichoderma reesei) Cel7B catalytic module. Eur J Biochem 2004, 271:1266-1276.

73. Hägglund P, Eriksson T, Collén A, Nerinckx W, Claeyssens M, Stålbrand H: A cellulose-binding module of the Trichoderma reesei $\beta$-mannanase Man5A 
increases the mannan-hydrolysis of complex substrates. J Biotechnol 2003, 101:37-48

74. Askerlund P, Larsson C, Widell S: Cytochromes of plant plasma membranes - characterization by absorbance difference spectrophotometry and redox titration. Physiol Plant 1989, 76:123-134.

75. Chen HJ, Hou WC, KuC J, Lin YH: $\mathrm{Ca}^{2+}$-dependent and $\mathrm{Ca}^{2+}$-independent excretion modes of salicylic acid in tobacco cell suspension culture. $J$ Exp Bot 2001, 52:1219-1226.

76. Larsson C, Sommarin M, Widell S: Isolation of highly purified plant plasma membranes and separation of inside-out and right-side-out vesicles. Meth Enzymol 1994, 228:451-469.

77. Widell S, Lundborg T, Larsson C: Plasma membranes from oats prepared by partition in an aqueous polymer two-phase system: On the use of light-induced cytochrome $b$ reduction as a marker for the plasma membrane. Plant Physiol 1982, 70:1429-1435.

78. Fredrikson K, Larsson C: Activation of 1,3- $\beta$-glucan synthase by $\mathrm{Ca}^{2+}$, spermine and cellobiose - Localization of activator sites using inside-out plasma membrane vesicles. Physiol Plant 1989, 77:196-201.

79. Widell S, Sommarin M: Purification of endoplasmic-reticulum from wheat roots and shoots (Triticum aestivum) - Comparison of their blue lightsensitive redox components with those of highly purified plasma membrane. Physiol Plant 1991, 82:9-18.

80. Bearden JJ: Quantitation of sub-microgram of protein by an improved protein-dye assay. Biochim Biophys Acta 1978, 533:525-529.

81. Merkouropoulos G, Andreasson E, Hess D, Boller T, Peck SC: An Arabidopsis protein phosphorylated in response to microbial elicitation, AtPHOS32, is a substrate of MAP kinases 3 and 6. J Biol Chem 2008, 283:10493-10499.

82. Sommarin M, Sandelius AS: Phosphatidylinositol and phosphatidylinositolphosphate kinases in plant plasma membranes. Biochim Biophys Acta 1988, 958:268-278.

83. Andersson MX, Larsson KE, Tjellström H, Liljenberg C, Sandelius AS: Phosphate-limited oat. The plasma membrane and the tonoplast as major targets for phospholipid-to-glycolipid replacement and stimulation of phospholipases in the plasma membrane. J Biol Chem 2005, 280:27578-27586

84. Christie WW: Lipid analysis: isolation, separation, identification and structural analysis of lipids. The Oily Press; 2003.

85. Baron CB, Coburn RF: Comparison of 2 copper reagents for detection of saturated and unsaturated neutral lipids by charring densitometry. J Liq Chromatogr 1984, 7:2793-2801.

86. Carlsson AS, Hellgren LI, Selldén G, Sandelius AS: Effects of moderately enhanced levels of ozone on the acyl lipid-composition of leaves of garden pea (Pisum sativum). Physiol Plant 1994, 91:754-762.

doi:10.1186/1471-2229-10-274

Cite this article as: Aidemark et al.: Trichoderma viride cellulase induces resistance to the antibiotic pore-forming peptide alamethicin associated with changes in the plasma membrane lipid composition of tobacco BY-2 cells. BMC Plant Biology 2010 10:274.

\section{Submit your next manuscript to BioMed Central and take full advantage of:}

- Convenient online submission

- Thorough peer review

- No space constraints or color figure charges

- Immediate publication on acceptance

- Inclusion in PubMed, CAS, Scopus and Google Scholar

- Research which is freely available for redistribution

Submit your manuscript at www.biomedcentral.com/submit 